\title{
No evidence for association of inherited variation in genes involved in mitosis and percent mammographic density
}

Celine M Vachon ${ }^{1 *}$, Jingmei Li ${ }^{3,4}$, Christopher G Scott ${ }^{1}$, Per Hall ${ }^{3}$, Kamila Czene ${ }^{3}$, Xianshu Wang ${ }^{2}$, Jianjun Liu4, Zachary S Fredericksen ${ }^{1}$, David N Rider ${ }^{1}$, Fang-Fang Wu', Janet E Olson ${ }^{1}$, Julie M Cunningham², Kristen N Stevens ${ }^{1}$, Thomas A Sellers ${ }^{5}$, Shane V Pankratz ${ }^{1}$ and Fergus J Couch ${ }^{2}$

\begin{abstract}
Introduction: Increased mammographic breast density is one of the strongest risk factors for breast cancer. While two-thirds of the variation in mammographic density appears to be genetically influenced, few variants have been identified. We examined the association of inherited variation in genes from pathways that mediate cell division with percent mammographic density (PMD) adjusted for age, body mass index (BMI) and postmenopausal hormones, in two studies of healthy postmenopausal women.

Methods: We investigated 2,058 single nucleotide polymorphisms (SNPs) in 378 genes involved in regulation of mitosis for associations with adjusted PMD among 484 unaffected postmenopausal controls (without breast cancer) from the Mayo Clinic Breast Cancer Study (MCBCS) and replicated the findings in postmenopausal controls $(n=726)$ from the Singapore and Sweden Breast Cancer Study (SASBAC) study. PMD was assessed in both studies by a computer-thresholding method (Cumulus) and linear regression approaches were used to assess the association of SNPs and PMD, adjusted for age, BMI and postmenopausal hormones. A P-value threshold of $4.2 \times 10^{-5}$ based on a Bonferroni correction of effective number of independent tests was used for statistical significance. Further, a pathway-level analysis was conducted of all 378 genes using the self-contained gene-set analysis method GLOSSI.

Results: A variant in PRPF4, rs10733604, was significantly associated with adjusted PMD in the MCBCS $(P=2.7 \times$ $10^{-7}$ ), otherwise, no single SNP was associated with PMD. Additionally, the pathway analysis provided no evidence of enrichment in the number of associations observed between SNPs in the mitotic genes and PMD $(P=0.60)$. We evaluated rs 10733604 (PRPF4), and 73 other SNPs at $P<0.05$ from 51 genes in the SASBAC study. There was no evidence of an association of rs 10733604 (PRPF4) with adjusted PMD in SASBAC ( $P=0.23)$. There were, however, consistent associations $(P<0.05)$ of variants at the putative locus, LOC375190, Aurora B kinase (AURKB), and Minichromosome maintenance complex component 3 (MCM3) with adjusted PMD, although these were not statistically significant.
\end{abstract}

Conclusions: Our findings do not support a role of inherited variation in genes involved in regulation of cell division and adjusted percent mammographic density in postmenopausal women.

\footnotetext{
* Correspondence: vachon.celine@mayo.edu

'Department of Health Sciences Research, Mayo Clinic College of Medicine,

Rochester, MN 55905, USA

Full list of author information is available at the end of the article
} 


\section{Introduction}

Mammographic density is a trait that represents the proportion of stromal and epithelial tissues in a radiographic image of the breast. Women with $>50 \%$ dense tissue are at an estimated four- to six-fold increased risk of breast cancer relative to those with $<10 \%[1,2]$.

Little is known about the biology of mammographic density or the mechanisms underlying the association between density and breast cancer. However, there is mounting evidence that genetic influences account for a large proportion of variation in mammographic density [3-5]. Indeed, it has been estimated that $61 \%$ to $67 \%$ of the variation in percent mammographic density adjusted for age and covariates, may be attributable to genetics [3]. To date, few loci have been shown associated with the mammographic density measures that predict breast cancer [6]. A recent study by Odefrey and colleagues [7] confirmed the association of a variant ( $\mathrm{rs} 3817198)$ in lymphocyte-specific protein 1, LSP1, with mammographic density. Importantly, this variant was initially identified as a breast cancer susceptibility locus [8]. Also, the first meta-analysis of genome-wide association studies of adjusted percent mammographic density identified an association with rs10995190 in ZNF365 [9], which has also been shown to be a risk factor for breast cancer [10]. Although these loci are promising, they explain little variation in the density measures and suggest other genetic variation for mammographic density remains to be determined.

Mammographic density has been hypothesized to reflect the cumulative exposure of breast stroma and epithelium to hormones and growth factors that can stimulate cell division and proliferation [11]. Evidence for this can be seen in the multiple studies showing positive associations of mammographic density with use of postmenopausal hormone therapy (PMH), especially estrogen and progesterone therapy [12-19], as well as with circulating IGF-1 (in premenopausal women) [20-23], both of which have been shown to exert proliferative effects on the breast. In one study of PMH, density, and tissue characteristics, PMH was associated with increased density, greater fibrous stroma, and less complex lobule type (lobule type 1), independent of estrogen and progesterone receptor up-regulation [24]. Increased density was also associated with Ki67 activity in the ducts and lobules [24], although this has not been confirmed in the majority of other studies [25-28]. These findings are consistent with the evidence that fibrous stroma differentiates dense and non-dense breast tissue [28-32]. Recent histologic studies that have compared targeted regions of dense and non-dense tissue in healthy patients suggest the proportion of connective tissue and relative cellularity of stromal cells is higher in dense vs. non-dense areas of the breast; this was not consistently seen or was seen to a lesser extent for the epithelial tissues $[28,33]$. We have also shown increased aromatase expression in stromal cells from dense vs. non-dense areas of the breast, which could result in increased production of estrogens, and consequent stimulation of cellular proliferation [34]. Furthermore, stromal cells can produce growth factors such as IGF-1 that may also stimulate proliferation through paracrine mechanisms $[24,35]$.

Genes involved in regulation of cell division or mitosis could mediate the influence of these endogenous and exogenous exposures on breast tissue, reflected in variations in mammographic density. For instance, virgin Sprague-Dawley rats treated with the placental hormone human chorionic gonadotropin (hCG) to mimic pregnancy show unique genomic signatures, including expression of genes involved in cell division control, which were not seen in rats receiving 17beta-estradiol and progesterone [36]. In addition, non-epithelial nuclear area, which may represent increased nuclear size due to failed or delayed cell division, has been associated with mammographic breast density in women over age 50 [37]. Here we present a comprehensive analysis of the association between variation in 378 genes involved in regulation of mitosis and mammographic density in postmenopausal women.

\section{Materials and methods \\ Study population}

The Mayo Clinic Breast Cancer Study (MCBCS) is an on-going clinic-based case-control study initiated in February 2001 at Mayo Clinic, Rochester, MN. Details of the study design and data collection procedures have been previously described [38]. Briefly, cases were women over age 20 years with histologically confirmed primary invasive breast carcinoma enrolled within six months of the date of diagnosis. Controls without prior history of cancer (other than non-melanoma skin cancer) were matched on age ( \pm 5 years) and region of residence to cases. Controls were selected from the outpatient clinic in the Department of Internal Medicine at Mayo Clinic where they were seen for general medical examinations. A self-administered risk factor questionnaire, blood sample, permission to obtain mammograms and written informed consent were obtained from all participants. Case participation was $69 \%(\mathrm{n}=798$ cases $)$ and control participation was $71 \%$ ( $\mathrm{n}=843$ controls). All subjects provided written, informed consent and the protocol was reviewed by the Mayo Clinic Institutional Review Board.

\section{Mammographic density measurement}

Mammograms were only ascertained on controls for this analysis, as the focus of the study was to understand the genetics of mammographic density among healthy 
women. The closest screening mammogram to enrollment date (median 0 days, $59 \%$ were same day, $82 \%$ within 1 year) was obtained and digitized on a Kodak Lumiscan 75 scanner (LS 75) (Lumisys/Eastman Kodak Co, Rochester, New York, USA) with 12-bit grayscale pixel depth for 686 of the 843 (81\%) control women; analyses focused on the 484 mammograms (of 579 postmen eligible or $84 \%$ ) from postmenopausal Caucasian women due to the composition of the SASBAC replication study. We estimated mammographic density using the cranial-caudal (CC) or top-down view from the left breast using a validated computer-assisted thresholding program (Cumulus [39] University of Toronto, Toronto, Ontario, Canada) that we have used in previous reports [40-42] and has been shown by our group to predict breast cancer [43]. We assessed percent mammographic density defined as the absolute area of dense tissue on the mammogram divided by the total area multiplied by 100. All images were read by one trained technician who consistently maintained high reliability $(r>0.90)$ while reading duplicate images across varying time frames $[41,43]$.

\section{Gene and SNP selection}

We identified genes encoding proteins involved in regulation of all aspects of cell division, identified through the literature and known pathways. Specifically, we chose genes implicated in mitotic entry, mitotic progression, the mitotic checkpoint, cytokinesis and mitotic exit. In addition, we included genes implicated in mitotic function through functional screens $[44,45]$ and genes involved in the structure and function of centrosomes [46], which are directly involved in chromosome segregation. SNPs representing common genetic variation within these 378 genes were identified and examined with percent mammographic density. SNP selection has been described in detail elsewhere $[38,46]$. Briefly, we first selected tagSNPs $\left(r^{2}>0.80\right)$ from SNPs with MAF $\geq 0.05$ located within $5 \mathrm{~kb}$ of the largest cDNA isoform (genome build 35) to represent a reduced set of SNPs in each gene [47]. We prioritized putative functional SNPs (within 1 kb upstream, 5' UTR, 3' UTR or non-synonymous) with MAF $\geq 0.05$ identified in Ensembl version 34. A total of 2,058 SNPs in 378 genes were identified.

As detailed elsewhere [38], samples from both cases and controls, (including 5\% duplicate samples), were assayed at Illumina Corporation (San Diego, CA, USA) on an Illumina BeadLab using the Illumina GoldenGate Assay ${ }^{\mathrm{TM}}$. DNA activation, incubation with assay oligonucleotides, PCR amplification and analysis using the BeadStudio software for automated genotype clustering and calling was performed according to a standard protocol [48-50]. Successful genotyping was achieved for 99.9\% of DNA samples (seven case DNAs failed).
Analyses of SNPs with mammographic density were limited to postmenopausal controls. We assessed departures from Hardy-Weinberg equilibrium (HWE) $(P<$ 0.001 ) in these 484 postmenopausal control subjects using a Pearson goodness-of-fit test. Of the 2,058 SNPs genotyped, 2,048 (99.5\%) were in HWE, and SNP call rates were $>99 \%$ in 2,041 SNPs (2,053 SNPs > 98\%). Also, only $24(5 \%)$ of the 484 had sample call rates below $98 \%$, but these were all above $95 \%$.

\section{SASBAC study}

The Singapore and Sweden Breast Cancer Study (SAS$\mathrm{BAC}$ ) is a population-based case-control study of postmenopausal breast cancer in women aged 50 to 74 years born in Sweden. Details on data collection and subjects have been described previously [51]. Controls were white Europeans randomly selected from the Swedish population and frequency matched to the expected age distribution of cases and on geographical area. They served as the replication sample for this study. The final study group with both mammographic density and genotype data included 726 controls of 764 eligible (95\%). Approval of the study was given by the ethical review board at the Karolinska Institute (Stockholm, Sweden) and six other ethical review boards in the respective regions in which the subjects were based.

Screening film mammograms corresponding to the enrollment date were obtained. The medio-lateral oblique (MLO) view was digitized using an Array 2905HD Laser Film Digitizer (Array Corporation, Roden, The Netherlands, which covers a range of 0 to 4.7 optical density. Similar to the MCBCS, the Cumulus software was used for determination of percent mammographic density on a randomly selected side. A random $10 \%$ of the images were included as replicates to assess the intra-observer reliability, which was high with a Spearman rank correlation coefficient of 0.95 .

Associations of any SNP with $P<0.05$ in MCBCS by the $\log$-additive test were attempted for in silico replication within SASBAC using available genotype information from a genome wide association study (GWAS) of breast cancer [52]. Briefly, 764 controls were genotyped on the HumanHap550 BeadChip; of these, 726 (95\%) controls had films available. When the exact SNP was genotyped and available as part of the SASBAC GWAS (which occurred $56 \%$ of the time), the corresponding $P$ value for that SNP was used. If the exact SNP was not available, we examined the association with available SNPs in high linkage disequilibrium (LD), defined as $\mathrm{r}^{2}$ $>0.70$ with the SNP of interest, using HapMap CEU.

\section{Mammographic density comparison studies}

We compared the similarity of percent mammographic density (PMD) assessment between the readers from 
MCBCS and SASBAC using a standard set of 20 film mammogram images across varying densities. The intrareader reliability assessed as the intraclass correlation or ICC for PMD between readers was high $(\mathrm{ICC}=0.99$; Figure 1). We also assessed the intraclass correlations between our readers with Dr. Norman Boyd, an expert in the estimation of density and found strong agreement (ICC $=0.98$ and 0.99 for MCBCS and SASBAC, respectively, Figure 1).

Further, since MCBCS and SASBAC ascertained and estimated PMD from different mammogram views (CC vs. MLO, respectively), we were interested in the differences in PMD between the two mammogram views. A previous study of 30 women found strong correlations of $\mathrm{CC}$ and MLO views (between 0.86 and 0.96 ), suggesting representative information is provided in a single view [53]. We conducted a larger study of 700 controls with both right and left CC and MLO views [43]. We examined the differences in mean PMD as well as Pearson correlations ( $r$ ) assessed from the CC and MLO views from the same breast. We found the average absolute difference in PMD between CC and MLO views to be $2.0 \%$ $(\mathrm{SD}=6.5)$ for the left and $2.2 \%(\mathrm{SD}=6.4 \%)$ for the right breast. The Pearson correlations between the PMD from CC and MLO were also very high, with $r=0.90$ for both left and right breasts (Figure 2).

\section{Statistical analysis}

Primary analyses focused on the 484 postmenopausal controls in the MCBCS study, since SASBAC was
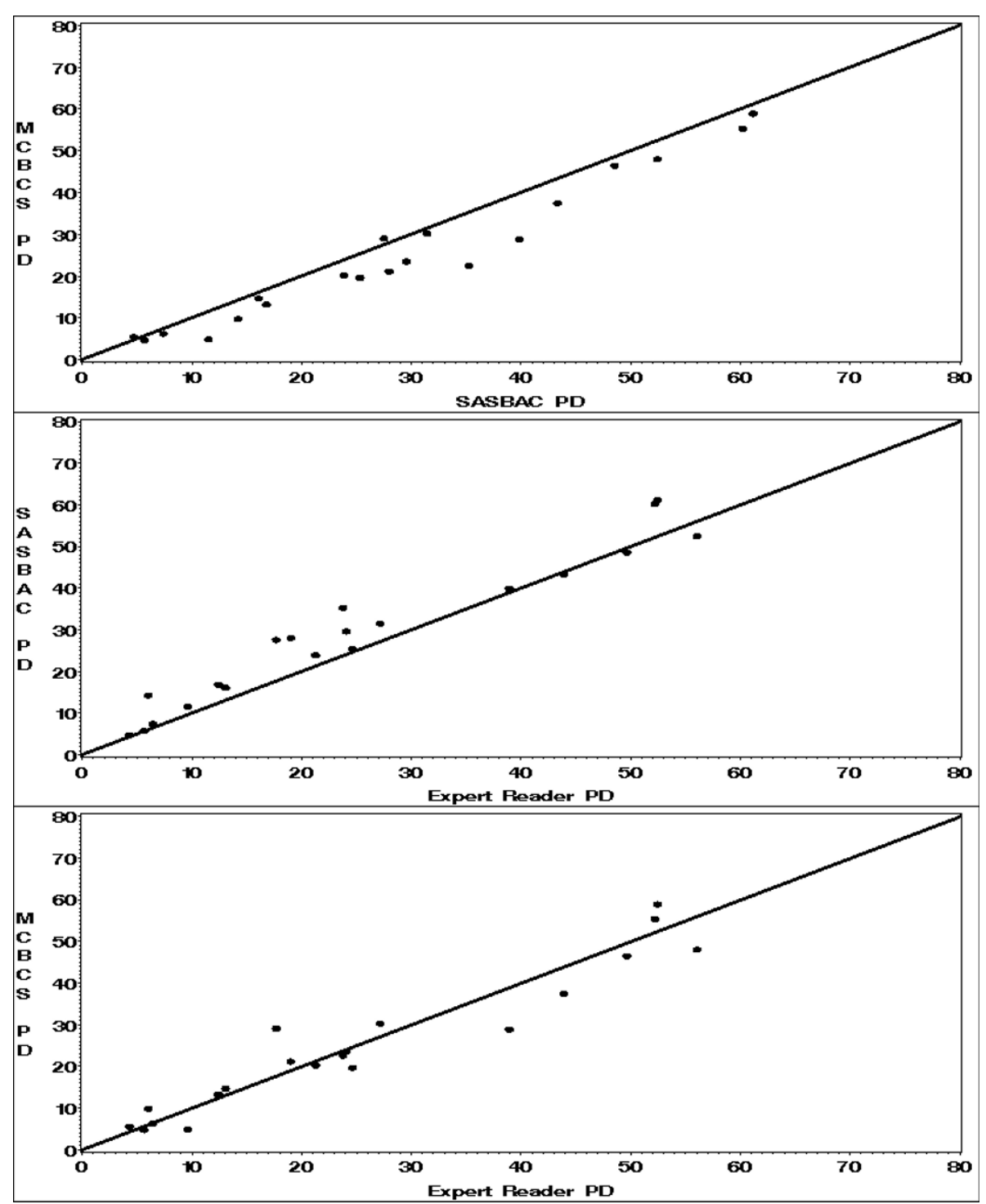

Figure 1 Comparison of percent mammographic density estimation among MCBCS, SASBAC, and expert readers. 


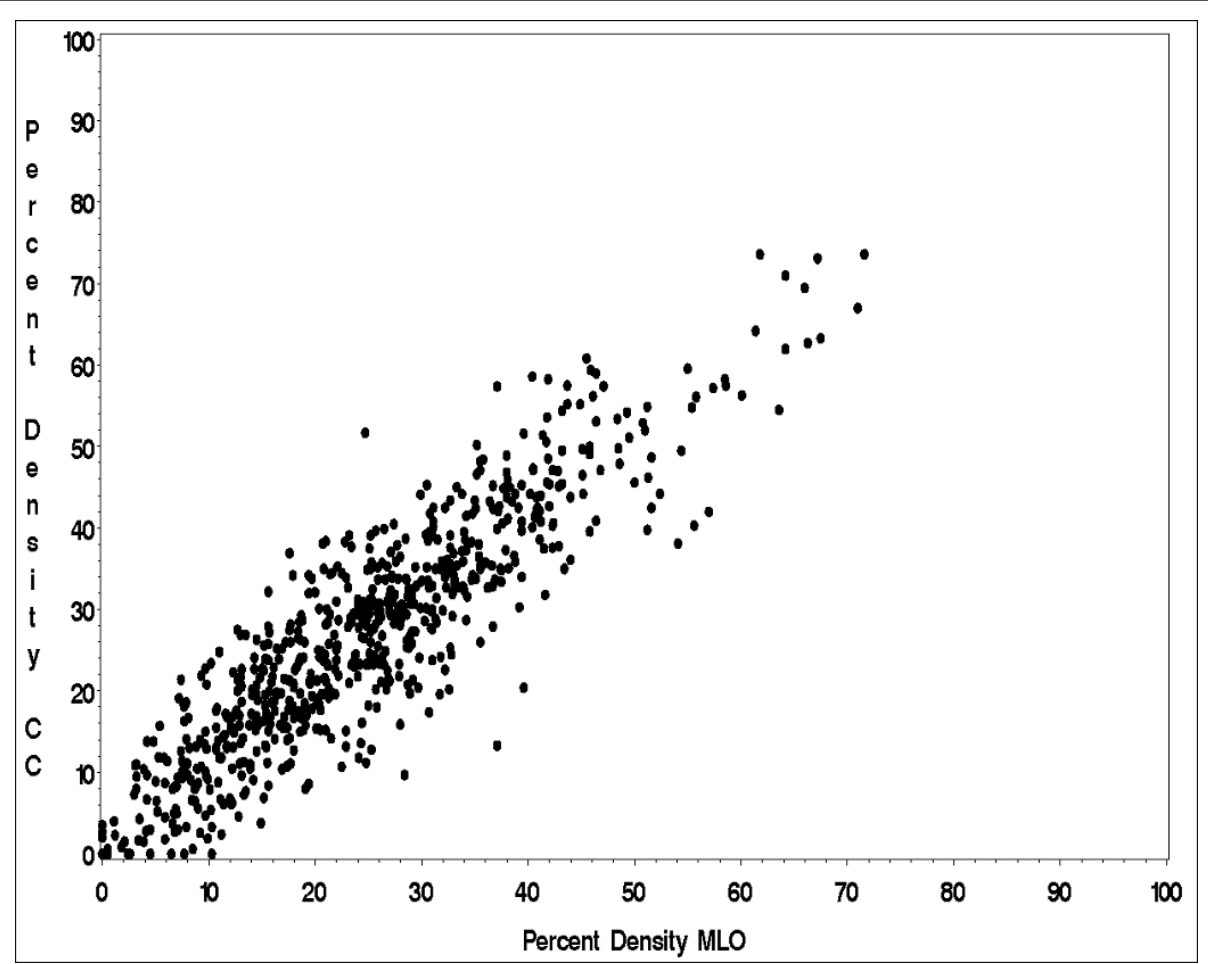

Figure 2 Comparison of percent mammographic density estimation on MLO vs. CC views from 700 controls [43].

comprised only of postmenopausal women. Initially, we examined the distribution of risk factors and mammographic density among postmenopausal controls from MCBCS and SASBAC. Genotypes from controls were used to estimate allele frequencies within each study set.

Individual SNP associations with PMD were assessed using linear regression. No transformation of PMD was made in MCBCS since residuals were approximately normal. Tests for associations were carried out assuming an ordinal (log-additive or additive) genotypic relationship using simple tests for trend within the linear regression models. All analyses were adjusted for age, body mass index (BMI) and current post-menopausal hormone (PMH) use. Examination of transformations of BMI and age did not result in substantial improvement in model fit when compared to models that were based on the original scale of these covariates. Because of this, and because linear regression assumptions were met in the analysis models, the original scale for these variables was used in all analyses on MCBCS data.

Similar analyses were performed for the replication of SNPs in the SASBAC sample with PMD, although a square root transformation of $\mathrm{PMD}$ was required to meet linear regression assumptions. Analyses were adjusted as above. Mean PMD from SASBAC was backtransformed for each genotype within the context of the general model in order to more directly compare results to those from MCBCS.

A pathway-level analysis was conducted using the selfcontained gene-set analysis method, GLOSSI [54]. This algorithm, based on Fisher's combined probability test, is designed to determine if the distribution of $P$-values in a set of genes deviates from what is expected based on the null hypothesis of no association. GLOSSI was implemented using 2,028 SNPs from the 378 genes among the 484 postmenopausal breast cancer-free controls in the MCBCS study to test for an association with this pathway and PMD adjusted for age, BMI and $\mathrm{PMH}$ use as above. A pathway-level $P$-value was obtained based on 500 permutations.

To assess heterogeneity of associations by study, a meta-analysis was performed on the ordinal parameter estimates and the Q-test was calculated [55]. In order to make the ordinal estimates comparable between studies for the meta-analysis, ordinal estimates for the MCBCS sample were estimated using square root transformed percent density within this sample. These parameter estimates were used to calculate the Q-test statistic and resulting heterogeneity $P$-value.

In order to set a threshold for statistical significance that appropriately reflects the number of SNPs tested, recognizing that SNPs within genes may not be independent, we calculated an effective number of 
independent tests within each gene using an eigenvalue based measure as proposed by Galwey [56]. We summed the effective number of independent tests per gene across all genes in the study to estimate the effective number of independent tests ( $n=1,178$ for stage I and $n=64$ for replication). We use this result to set our threshold for significance via a Bonferroni correction for the number of independent tests $\left(0.05 / 1,178=4.2 \times 10^{-}\right.$ 5 for stage I and $0.05 / 64=7.8 \times 10^{-4}$ for replication). Analyses were implemented using SAS (SAS Institute, Cary, NC, USA, Version 8, 1999), S-Plus (Insightful Corp, Seattle, WA, USA, Version 7.05, 2005) and R software systems.

\section{Results}

The 2,058 SNPs from 378 genes were examined for associations with PMD among 484 postmenopausal women within MCBCS. Characteristics of the MCBCS postmenopausal controls are described in Table 1. One variant, rs10733604 in PRPF4, was associated with adjusted PMD $\left(P=2.7 \times 10^{-7}\right)$. A second, albeit not statistically significant, association was seen with rs12563929 in PRKACB $\left(P=2.2 \times 10^{-4}\right)$ (Additional file $1)$. In total, we found 88 SNPs in 58 genes associated at $P<0.05$ with percent density. These SNPs were selected for examination within the SASBAC study (Additional file 1). The pathway analysis incorporating all 378 genes showed no evidence of enrichment in the number of associations observed between SNPs in the mitotic genes and $\operatorname{PMD}(P=0.60)$.
The 726 controls from SASBAC were slightly younger (mean age $62.8 \pm 6.2$ vs. $63.6 \pm 9.2$ ), less likely to use $\mathrm{PMH}(38.7 \%$ vs. $65.3 \%)$ and had lower average BMI (25.7 vs. 26.9) and PMD (14.4\% vs. 18.6\%) than the MCBCS controls (Table 1). Both studies showed inverse associations of age and BMI with PMD and positive associations with current PMH use (Table 2).

Within SASBAC, genotype information was available for 73 of the 88 SNPs (located in 51 genes) associated with PMD at $P<0.05$ in MCBCS. Of these, 56\% were the exact SNP but the remainder were SNPs in moderate to high linkage disequilibrium (LD > 0.70) with the SNP of interest within MCBCS. Both of the SNPs rs10733604 in PRPF4 and rs12563929 in PRKACB were available in SASBAC (noted in Additional file 1).

There were no associations of $\operatorname{rs} 10733604(P=0.23)$ or rs12563929 $(P=0.93)$ with percent density in the SASBAC study. Eight of the 73 (10.9\%) candidate SNPs, located in seven genes, displayed associations also at $P<$ 0.05 with PMD in the SASBAC study (Table 3), although none reached the statistical threshold. Only variants in LOC375190 (rs2080727) AURKB (rs4792590 and rs3027260, LD of $\mathrm{r}^{2}=0.71$ ) and MCM3 (rs3765447), showed consistent direction of effect in both the MCBCS and SASBAC studies, which was also reflected in the tests of heterogeneity (Table 3 ).

\section{Discussion}

Overall, we found no statistically significant associations between SNPs involved in mitosis with percent

Table 1 Characteristics of two postmenopausal control populations (MCBCS ${ }^{a}, 2001-2005$ and SASBAC $^{b}$, 1993-1995).

\begin{tabular}{|c|c|c|c|c|c|}
\hline \multirow[t]{2}{*}{ Characteristic } & \multirow[t]{2}{*}{ Level } & \multicolumn{2}{|c|}{$\begin{array}{c}\text { MCBCS }^{a} \\
(n=484)\end{array}$} & \multicolumn{2}{|c|}{$\begin{array}{l}\text { SASBAC }^{b} \\
(n=726)\end{array}$} \\
\hline & & $\mathrm{N}$ & $\%$ or mean & $\mathbf{N}$ & $\%$ or mean \\
\hline \multirow[t]{4}{*}{ Age, years } & 40 to 49 & 26 & 5.4 & 1 & 0.1 \\
\hline & 50 to 59 & 157 & 32.4 & 237 & 32.6 \\
\hline & 60 to 69 & 176 & 36.4 & 363 & 50.0 \\
\hline & $70+$ & 125 & 25.8 & 125 & 17.2 \\
\hline Body mass index, $\mathrm{kg} / \mathrm{m}^{2}$ & Mean (SD) & 464 & $26.9(5.3)$ & 718 & $25.7(4.1)$ \\
\hline \multirow[t]{4}{*}{ Postmenopausal hormone use } & Current & 153 & 31.6 & 95 & 13.1 \\
\hline & Former & 163 & 33.7 & 186 & 25.6 \\
\hline & Never & 136 & 28.1 & 362 & 49.9 \\
\hline & Unknown & 32 & 6.6 & 83 & 11.4 \\
\hline Percent Mammographic Density, (\%) & Mean (SD) & 484 & $18.6(13.9)$ & 726 & $14.4(13.9)$ \\
\hline \multirow[t]{6}{*}{ Categories } & 0 & 30 & 6.2 & 45 & 6.2 \\
\hline & 1 to 9 & 116 & 24.0 & 324 & 44.6 \\
\hline & 10 to 24 & 201 & 41.5 & 225 & 31.0 \\
\hline & 25 to 49 & 125 & 25.8 & 111 & 15.3 \\
\hline & 50 to 74 & 11 & 2.3 & 21 & 2.9 \\
\hline & $75+$ & 1 & 0.2 & 0 & 0 \\
\hline
\end{tabular}

${ }^{\mathrm{a}}$ Mayo Clinic Breast Cancer Study. ${ }^{\mathrm{b}}$ Singapore and Sweden Breast Cancer Study. 
Table 2 Adjusted mean percent mammographic density by age, BMI, postmenopausal hormone use (MCBCS and SASBAC controls) $)^{a}$.

\begin{tabular}{|c|c|c|c|c|c|}
\hline \multirow[t]{2}{*}{ Characteristic } & \multirow[t]{2}{*}{ Level } & \multicolumn{2}{|c|}{$\begin{array}{c}\text { MCBCS } \\
\text { Controls } \\
(n=484)\end{array}$} & \multicolumn{2}{|c|}{$\begin{array}{l}\text { SASBAC } \\
\text { Controls } \\
(n=726)\end{array}$} \\
\hline & & Mean & $95 \% \mathrm{Cl}$ & Mean & $95 \% \mathrm{Cl}$ \\
\hline \multirow[t]{4}{*}{ Age, years } & 40 to 49 & 23.6 & 18.3 to 28.9 & 8.2 & -——-— \\
\hline & 50 to 59 & 20.1 & 17.9 to 22.2 & 16.7 & 14.9 to 18.6 \\
\hline & 60 to 69 & 18.2 & 16.1 to 20.2 & 13.7 & 12.4 to 15.1 \\
\hline & $70+$ & 16.4 & 14.0 to 18.8 & 12.0 & 9.5 to 14.5 \\
\hline \multirow[t]{4}{*}{ Body mass index, $\mathrm{kg} / \mathrm{m}^{2 b}$} & $<25$ & 24.8 & 24.0 to 27.6 & 19.2 & 17.5 to 20.8 \\
\hline & 25 to 30 & 16.0 & 14.2 to 17.9 & 11.2 & 10.0 to 12.5 \\
\hline & $>30$ & 10.6 & 8.2 to 13.0 & 6.8 & 5.1 to 8.5 \\
\hline & Unknown & 15.9 & 10.2 to 21.5 & 10.5 & 3.9 to 17.2 \\
\hline \multirow[t]{4}{*}{ Postmenopausal hormone use $\mathrm{e}^{c}$} & Current & 21.9 & 19.8 to 24.0 & 19.6 & 16.4 to 22.7 \\
\hline & Former & 18.1 & 16.1 to 20.2 & 17.0 & 14.9 to 19.1 \\
\hline & Never & 15.6 & 13.4 to 17.9 & 11.7 & 10.6 to 12.8 \\
\hline & Unknown & 18.3 & 12.7 to 23.9 & 14.7 & 11.8 to 17.6 \\
\hline
\end{tabular}

${ }^{a}$ Mayo Clinic Breast Cancer Study; Singapore and Sweden Breast Cancer Study.

${ }^{\mathrm{b}}$ Adjusted for age. 'Adjusted for age and BMI.

mammographic density. There were consistent associations (albeit only at a significance of $P<0.05$ ) among four SNPs in three genes involved in either cell division (AURKB AND LOC375190) or cellular proliferation (MCM3) and adjusted percent density among two studies of postmenopausal women. These associations warrant further investigation.

Strengths of this study include examination of a novel pathway with adjusted percent mammographic density, SNP associations examined in two independent populations, similar quantitative measures of density used in both studies, adjustment for potential confounding factors, and focus on the homogenous subgroup of postmenopausal, healthy women. Also, non-replication of associations in the SASBAC study did not appear to be due to systematic differences in the readers' performance or mammogram view assessed, as our comparison studies suggested estimates were similar for both readers across a common set of images as well as by MLO vs. CC views. However, limitations include inability to confirm associations for 15 SNPs and use of different digitizers that could potentially add systematic bias to the percent density estimation.

Although very little is known about the biology underlying mammographic density, evidence strongly suggests that genes contribute to a large proportion of the variation in density $[3,4,7,9]$. To date, replicated associations between genetic variants associated with a few candidate genes, including IGF-1, ESR1, HSD3B1, and COMT and breast density have been observed, implicating primarily pathways that regulate steroid hormone synthesis and metabolism, hormone receptors and proliferative pathways, including the insulin-like growth factor pathway
[6]. Our study is the first to perform a comprehensive analysis of candidate genes in mitosis. However, our results do not suggest a strong role of genes involved in mitosis with percent mammographic density.

Interestingly, two of the genetic loci ( $A U R K B$, LOC375190) containing SNPs that displayed consistent, albeit nonsignificant, associations with adjusted percent mammographic density in the MCBCS and SASBAC studies, have been implicated in the regulation of the metaphase to anaphase transition during chromosome segregation. Although little is known about the protein encoded by LOC375190, a functional siRNA based screen has shown that reduced levels of LOC 375190 causes severe spindle defects and mitotic arrest and subsequent formation of polyploid cells due to premature mitotic exit [44]. In contrast, much is known about the role of the AURKB-encoded Aurora B protein in mitotic regulation. While Aurora $B$ has been implicated in mitotic entry and also in cytokinesis and mitotic exit, the primary role for this kinase is in the assembly of factors involved in spindle attachment and tension and regulation of the mitotic checkpoint. Loss or gain of Aurora B results in defects in the metaphase to anaphase transition and subsequent aneuploidy due to chromosome segregation defects or polyploidy due to premature mitotic exit. Interestingly, Aurora B is localized at centrosomes during mitosis and may influence spindle growth from the centrosome to the kinetochore during mitosis, similar to LOC 375190, resulting in defects in chromosome segregation and/or premature mitotic exit [57]. Given these common functions, it is tempting to speculate that common genetic variation in these two loci may result in defects in chromosome segregation, 
Table 3 Polymorphisms in mitotic pathway genes ${ }^{a}$ and percent mammographic density among $\operatorname{MCBCS}^{b}(n=484)$ and $\operatorname{SASBAC}^{b}(\mathbf{n}=726)$ controls.

\begin{tabular}{|c|c|c|c|c|c|c|c|c|c|c|c|}
\hline \multirow[b]{2}{*}{ Chr } & \multirow[b]{2}{*}{ Gene Name } & \multirow[b]{2}{*}{ Effect } & \multirow[b]{2}{*}{ SNP } & \multirow[b]{2}{*}{ Position (bp) } & \multicolumn{3}{|c|}{ MCBCS } & \multicolumn{3}{|c|}{ SASBAC } & \multirow[b]{2}{*}{ P-Het ${ }^{f}$} \\
\hline & & & & & $\mathrm{N}$ & $\begin{array}{c}\text { PMD } \\
\text { Est (SE)/ } \\
\text { adj mean }\end{array}$ & $P$-value ${ }^{d}$ & $\mathrm{~N}$ & $\begin{array}{l}\text { Sqrt PMD Est (SE)/ } \\
\text { adj mean }^{\mathrm{e}}\end{array}$ & $P$-value ${ }^{d}$ & \\
\hline \multirow[t]{4}{*}{1} & GALNT2 & Ordinal & rs1043908 & 228483917 & 484 & $2.88(1.28)$ & 0.025 & 725 & $-0.314(0.135)$ & 0.02 & $<0.001$ \\
\hline & & $\mathrm{A} / \mathrm{A}$ & & & 373 & 17.9 & & 555 & 19.0 & & \\
\hline & & $\mathrm{A} / \mathrm{G}$ & & & 102 & 20.8 & & 158 & 16.3 & & \\
\hline & & $\mathrm{G} / \mathrm{G}$ & & & 9 & 23.6 & & 12 & 13.9 & & \\
\hline \multirow[t]{4}{*}{2} & LOC375190 & Ordinal & rs2080727 & 24204411 & 484 & $1.69(0.85)$ & 0.048 & 725 & $0.185(0.095)$ & 0.05 & 0.54 \\
\hline & & $\mathrm{A} / \mathrm{A}$ & & & 195 & 17.2 & & 305 & 17.1 & & \\
\hline & & $\mathrm{A} / \mathrm{G}$ & & & 215 & 19.4 & & 332 & 18.7 & & \\
\hline & & $\mathrm{G} / \mathrm{G}$ & & & 74 & 20.2 & & 88 & 20.3 & & \\
\hline \multirow[t]{4}{*}{6} & MCM3 & Ordinal & rs3765447 & 52249471 & 483 & $3.62(1.76)$ & 0.040 & 725 & $0.45(0.188)$ & 0.017 & 0.96 \\
\hline & & $\mathrm{A} / \mathrm{A}$ & & & 422 & 18.2 & & 644 & 17.7 & & \\
\hline & & $\mathrm{A} / \mathrm{G}$ & & & 60 & 22.3 & & 76 & 21.7 & & \\
\hline & & $\mathrm{G} / \mathrm{G}$ & & & 1 & 12.7 & & 5 & 26.1 & & \\
\hline \multirow[t]{4}{*}{8} & TNKS & Ordinal & rs12549064 & 9479437 & 484 & $-2.15(1.09)$ & 0.048 & 725 & $0.321(0.116)$ & 0.006 & 0.001 \\
\hline & & $\mathrm{A} / \mathrm{A}$ & & & 303 & 19.5 & & 496 & 17.8 & & \\
\hline & & $\mathrm{A} / \mathrm{C}$ & & & 166 & 17.4 & & 205 & 20.6 & & \\
\hline & & $\mathrm{C} / \mathrm{C}$ & & & 15 & 15.1 & & 24 & 23.6 & & \\
\hline \multirow[t]{4}{*}{10} & KIF11 & Ordinal & rs2275220 & 94362686 & 484 & $-4.23(2.12)$ & 0.046 & 726 & $0.45(0.172)$ & 0.009 & 0.005 \\
\hline & & $\mathrm{A} / \mathrm{A}$ & & & 448 & 19.0 & & 613 & 17.9 & & \\
\hline & & $\mathrm{A} / \mathrm{G}$ & & & 34 & 13.5 & & 111 & 22.0 & & \\
\hline & & $\mathrm{G} / \mathrm{G}$ & & & 2 & 20.4 & & 2 & 26.4 & & \\
\hline \multirow[t]{4}{*}{11} & STIM1 & Ordinal & rs3794050 & 4068476 & 484 & 2.85 (1.38) & 0.039 & 726 & $-0.383(0.142)$ & 0.007 & 0.003 \\
\hline & & $\mathrm{G} / \mathrm{G}$ & & & 389 & 17.8 & & 547 & 19.4 & & \\
\hline & & $\mathrm{G} / \mathrm{A}$ & & & 89 & 23.0 & & 173 & 16.2 & & \\
\hline & & $\mathrm{A} / \mathrm{A}$ & & & 6 & 8.6 & & 6 & 13.3 & & \\
\hline \multirow[t]{8}{*}{17} & $A \cup R K B$ & Ordinal & rs3027260 & 8053911 & 484 & $-3.33(1.52)$ & 0.029 & 726 & $-0.404(0.177)$ & 0.022 & 0.73 \\
\hline & & $\mathrm{G} / \mathrm{G}$ & & & 404 & 19.2 & & 632 & 18.7 & & \\
\hline & & $\mathrm{G} / \mathrm{A}$ & & & 77 & 15.8 & & 91 & 15.4 & & \\
\hline & & $\mathrm{A} / \mathrm{A}$ & & & 3 & 12.8 & & 3 & 12.4 & & \\
\hline & & Ordinal & rs4792590 & 8057840 & 484 & $-3.14(1.34)$ & 0.020 & 726 & $-0.39(0.152)$ & 0.010 & 0.89 \\
\hline & & $\mathrm{G} / \mathrm{G}$ & & & 377 & 19.3 & & 597 & 18.6 & & \\
\hline & & $\mathrm{G} / \mathrm{A}$ & & & 102 & 16.6 & & 121 & 15.4 & & \\
\hline & & $\mathrm{A} / \mathrm{A}$ & & & 5 & 9.5 & & 8 & 12.5 & & \\
\hline
\end{tabular}

${ }^{\mathrm{a}} P \leq 0.05$ in both studies. ${ }^{\mathrm{b}}$ Mayo Clinic Breast Cancer Study; Singapore and Sweden Breast Cancer Study.

'PMD Est(SE): ordinal parameter estimate and standard error reflecting the estimated change in percent density per each additional copy of the minor allele carried. Adjusted mean from general model: least squares estimate of mean percent density for each genotype, adjusted for age, BMI, and PMH. ${ }^{\mathrm{d}} P$-value from

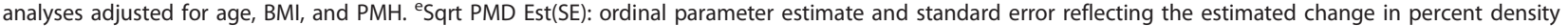
error per each additional copy of the minor allele carried. Adjusted mean from general model: least squares estimate of mean percent density for each genotype, adjusted for age, BMI, and PMH. Least squares means back transformed from square root to original scale. ${ }^{f} P$-value from test for heterogeneity from metaanalysis performed on the ordinal parameter estimates (ordinal estimates for the MCBCS sample were estimated using square root transformed PMD).

premature mitotic exit and an increase in the number of cells with multiple nuclei.

Since non-epithelial nuclear area, which may represent increased nuclear size due to failed or delayed cell division, has been associated with mammographic breast density in women over age 50 [37], studies of cell division in dense and non-dense mammary tissues may provide further insight into the associations reported here. However, since these proteins are multifunctional and may influence other cellular processes, including growth factors [58], alternative explanations for the associations with density must also be considered.

The third locus of interest, a variant in mini-chromosome maintenance complex component 3 or MCM3, however, plays a role in cellular proliferation. The protein encoded by MCM3 is one of the highly conserved mini-chromosome maintenance proteins (MCM) that are involved in the initiation of genome replication. The 
acetylation of this protein inhibits the initiation of DNA replication and cell cycle progression. Proliferation of stroma and/or epithelium has been hypothesized to underlie increased mammographic density [11], although few studies have shown positive associations between proliferation markers and PMD $[24,26,27,59]$ or tissue from dense areas of the breast [28].

\section{Conclusion}

In summary, we present the first report of variation in genes involved in regulation of cell division and mammographic density. We find no strong evidence of association between variants in genes involved in mitosis and adjusted percent mammographic density; however, further investigation of variants in AURKB, LOC375190 and $M C M 3$ is warranted.

\section{Additional material}

Additional file 1: Associations between variants in genes in the mitotic pathway and percent mammographic density (PMD) in two studies of postmenopausal women.484 Caucasian subjects from the Mayo Clinic Breast Cancer Study (MCBCS, 2001 to 2005) and 726 Caucasian subjects (controls) from Singapore and Sweden Breast Cancer Study (SASBC, 1993-1995).

\section{Abbreviations}

AURKB: Aurora B Kinase; BMI: Body Mass Index; CC: cranio-caudal; CEU: One of 11 populations in the Hapmap (Northern and Western European Ancestry); GWAS: genome wide association study; hCG: human chorionic gonadotropin; HWE: Hardy-Weinberg equilibrium; LD: linkage disequilibrium; MCBCS: Mayo Clinic Breast Cancer Study; MCM3: mini-chromosome maintenance complex component 3; MLO: medio-lateral oblique; PMH: postmenopausal hormones; PMD: Percent Mammographic Density; SASBAC: Sweden and Singapore Breast Cancer Study; SNP: single nucleotide polymorphism
\end{abstract}

\section{Acknowledgements}

This work was supported by grants from the National Institutes of Health (R01 CA128931; P50 CA116201; R01 CA122340; R01 CA58427); Märit and Hans Rausing's Initiative Against Breast Cancer; W81XWH-05-1-0314 Innovator Award; JLi is a recipient of the A*STAR Graduate Scholarship. KC was supported by the Swedish Cancer Society (5128-B07-01PAF).

\section{Author details \\ 'Department of Health Sciences Research, Mayo Clinic College of Medicine, Rochester, MN 55905, USA. ²Department of Laboratory Medicine and Pathology, Mayo Clinic College of Medicine, Rochester, MN 55905, USA. ${ }^{3}$ Department of Medical Epidemiology and Biostatistics, Karolinska Institute, Box 281, Stockholm 17177, Sweden. ${ }^{4}$ Human Genetics, Genome Institute of Singapore, Singapore 138672. ${ }^{5}$ Department of Epidemiology and Genetics, Moffitt Cancer Center, Tampa, FL 33612, USA.}

\section{Authors' contributions}

CMV, FJC, JEO and TAS contributed to all aspects of the study, including study design, data collection, analyses, interpretation and preparation of the manuscript. XW, JMC and DNR were responsible for samples and genotyping for MCBCS. JLi, PH, KC and JLiu contributed to the SASBAC replication results, interpretation and publication. VSP, ZSF, CGS and JLi conducted statistical analyses and provided results. KNS performed the pathway analyses and provided interpretation of results and scientific review of the manuscript. FFW was responsible for all aspects of mammogram retrieval and mammographic density estimation. All authors read and approved the final manuscript.

\section{Competing interests}

The authors declare that they have no competing interests.

Received: 15 February 2011 Revised: 1 December 2011

Accepted: 7 January 2012 Published: 7 January 2012

\section{References}

1. Cummings SR, Tice JA, Bauer S, Browner WS, Cuzick J, Ziv E, Vogel V, Shepherd J, Vachon C, Smith-Bindman R, Kerlikowske K: Prevention of breast cancer in postmenopausal women: approaches to estimating and reducing risk. J Natl Cancer Inst 2009, 101:384-398.

2. McCormack VA, dos Santos Silva I: Breast density and parenchymal patterns as markers of breast cancer risk: a meta-analysis. Cancer Epidemiol Biomarkers Prev 2006, 15:1159-1169.

3. Boyd NF, Dite GS, Stone J, Gunasekara A, English DR, McCredie MR, Giles GG, Tritchler D, Chiarelli A, Yaffe MJ, Hopper JL: Heritability of mammographic density, a risk factor for breast cancer. $N$ Engl J Med 2002, 347:886-894.

4. Vachon CM, Sellers TA, Carlson EE, Cunningham JM, Hilker CA, Smalley RL, Schaid DJ, Kelemen LE, Couch FJ, Pankratz VS: Strong evidence of a genetic determinant for mammographic density, a major risk factor for breast cancer. Cancer Res 2007, 67:8412-8418.

5. Pankow JS, Vachon CM, Kuni CC, King RA, Arnett DK, Grabrick DM, Rich SS, Anderson VE, Sellers TA: Genetic analysis of mammographic breast density in adult women: evidence of a gene effect. J Natl Cancer Inst 1997, 89:549-556.

6. Kelemen LE, Sellers TA, Vachon CM: Can genes for mammographic density inform cancer aetiology? Nat Rev 2008, 8:812-823.

7. Odefrey F, Stone J, Gurrin LC, Byrnes GB, Apicella C, Dite GS, Cawson JN, Giles GG, Treloar SA, English DR, Hopper JL, Southey MC, Australian Twins and Sisters Mammographic Density Study: Common genetic variants associated with breast cancer and mammographic density measures that predict disease. Cancer Res 2010, 70:1449-1458.

8. Easton DF, Pooley KA, Dunning AM, Pharoah PD, Thompson D, Ballinger DG, Struewing JP, Morrison J, Field H, Luben R, Wareham N, Ahmed S, Healey CS, Bowman R, SEARCH collaborators, Meyer KB, Haiman CA, Kolonel LK, Henderson BE, Le Marchand L, Brennan P, Sangrajrang S, Gaborieau V, Odefrey F, Shen CY, Wu PE, Wang HC, Eccles D, Evans DG, Peto J, et al: Genome-wide association study identifies novel breast cancer susceptibility loci. Nature 2007, 447:1087-1093.

9. Lindström S, Vachon CM, Li J, Varghese J, Thompson D, Warren R, Brown J, Leyland J, Audley T, Wareham NJ, Loos RJ, Paterson AD, Rommens J, Waggott D, Martin LJ, Scott CG, Pankratz VS, Hankinson SE, Hazra A, Hunter DJ, Hopper JL, Southey MC, Chanock SJ, Silva Idos S, Liu J, Eriksson L, Couch FJ, Stone J, Apicella C, Czene K, et al: Common variants in ZNF365 are associated with both mammographic density and breast cancer risk. Nat Genet 2011, 43:185-187.

10. Turnbull C, Ahmed S, Morrison J, Pernet D, Renwick A, Maranian M, Seal S, Ghoussaini M, Hines S, Healey CS, Hughes D, Warren-Perry M, Tapper W, Eccles D, Evans DG, Breast Cancer Susceptibility Collaboration (UK), Hooning M, Schutte M, van den Ouweland A, Houlston R, Ross G, Langford C, Pharoah PD, Stratton MR, Dunning AM, Rahman N, Easton DF: Genome-wide association study identifies five new breast cancer susceptibility loci. Nat Genet 2010, 42:504-507.

11. Boyd NF, Martin LJ, Bronskill M, Yaffe MJ, Duric N, Minkin S: Breast tissue composition and susceptibility to breast cancer. J Natl Cancer Inst 2010, 102:1224-1237.

12. Boyd NF, Melnichouk O, Martin L, Hislop G, Chiarelli AM, Yaffe MJ, Minkin S: Mammographic density, response to hormones, and breast cancer risk. J Clin Oncol 2011, 29:2985-2992.

13. Greendale GA, Reboussin BA, Sie A, Singh HR, Olson LK, Gatewood O, Bassett LW, Wasilauskas C, Bush T, Barrett-Connor E: Effects of estrogen and estrogen-progestin on mammographic parenchymal density. Postmenopausal Estrogen/Progestin Interventions (PEPI) Investigators. Ann Intern Med 1999, 130:262-269.

14. Laya MB, Gallagher JC, Schreiman JS, Larson EB, Watson P, Weinstein L: Effect of postmenopausal hormonal replacement therapy on 
mammographic density and parenchymal pattern. Radiology 1995, 196:433-437.

15. Stomper PC, Van Voorhis BJ, Ravnikar VA, Meyer JE: Mammographic changes associated with postmenopausal hormone replacement therapy: a longitudinal study. Radiology 1990, 174:487-490.

16. Marugg RC, van der Mooren MJ, Hendriks JH, Rolland R, Ruijs SH: Mammographic changes in postmenopausal women on hormonal replacement therapy. Eur Radiol 1997, 7:749-755.

17. Rutter CM, Mandelson MT, Laya MB, Seger DJ, Taplin S: Changes in breast density associated with initiation, discontinuation, and continuing use of hormone replacement therapy. JAMA 2001, 285:171-176.

18. McTiernan A, Chlebowski RT, Martin C, Peck JD, Aragaki A, Pisano ED, Wang CY, Johnson KC, Manson JE, Wallace RB, Vitolins MZ, Heiss G: Conjugated equine estrogen influence on mammographic density in postmenopausal women in a substudy of the women's health initiative randomized trial. J Clin Oncol 2009, 27:6135-6143.

19. McTiernan A, Martin CF, Peck JD, Aragaki AK, Chlebowski RT, Pisano ED, Wang CY, Brunner RL, Johnson KC, Manson JE, Lewis CE, Kotchen JM, Hulka BS, Women's Health Initiative Mammogram Density Study Investigators: Estrogen-plus-progestin use and mammographic density in postmenopausal women: women's health initiative randomized trial. J Natl Cancer Inst 2005, 97:1366-1376.

20. Byrne C, Colditz GA, Willett WC, Speizer FE, Pollak M, Hankinson SE: Plasma insulin-like growth factor (IGF) I, IGF-binding protein 3, and mammographic density. Cancer Res 2000, 60:3744-3748.

21. Diorio C, Pollak M, Byrne C, Masse B, Hebert-Croteau N, Yaffe M, Cote G, Berube S, Morin C, Brisson J: Insulin-like growth factor-l, IGF-binding protein-3, and mammographic breast density. Cancer Epidemiol Biomarkers Prev 2005, 14:1065-1073.

22. Boyd NF, Stone J, Martin LJ, Jong R, Fishell E, Yaffe M, Hammond G, Minkin S: The association of breast mitogens with mammographic densities. Br J Cancer 2002, 87:876-882.

23. Verheus $M$, Peeters $P H$, Kaaks $R$, vanNoord PA, Grobbee DE, vanGils CH: Premenopausal insulin-like growth factor-I serum levels and changes in breast density over menopause. Cancer Epidemiol Biomarkers Prev 2007, 16:451-7.

24. Harvey JA, Santen RJ, Petroni GR, Bovbjerg VE, Smolkin ME, Sheriff FS, Russo J: Histologic changes in the breast with menopausal hormone therapy use: correlation with breast density, estrogen receptor, progesterone receptor, and proliferation indices. Menopause 2008, 15:67-73.

25. Verheus M, Maskarinec G, Erber E, Steude JS, Killeen J, Hernandez BY, Cline JM: Mammographic density and epithelial histopathologic markers. BMC Cancer 2009, 9:182.

26. Khan QJ, Kimler BF, O'Dea AP, Zalles CM, Sharma P: Mammographic density does not correlate with Ki-67 expression or cytomorphology in benign breast cells obtained by random periareolar fine needle aspiration from women at high risk for breast cancer. Breast Cancer Res 2007, 9:R35.

27. Stomper PC, Penetrante RB, Edge SB, Arredondo MA, Blumenson LE, Stewart CC: Cellular proliferative activity of mammographic normal dense and fatty tissue determined by DNA S phase percentage. Breast Cancer Res Treat 1996, 37:229-236.

28. Ghosh K, Brandt KR, Reynolds C, Scott CG, Pankratz VS, Riehle DL, Lingle WL, Odogwu T, Radisky DC, Visscher DW, Ingle JN, Hartmann LC, Vachon CM: Tissue composition of mammographically dense and nondense breast tissue. Breast Cancer Res Treat 2012, 131:267-275.

29. Fisher ER, Palekar A, Kim WS: The histopathology of mammographic patterns. Am J Clin Pathol 1978, 69:421-426.

30. Wellings SR, Wolfe JN: Correlative studies of the histological and radiographic appearance of the breast parenchyma. Radiology 1978 129:299-306.

31. Arthur JE, Ellis IO, Flowers C, Roebuck E, Elston CW, Blamey RW: The relationship of "high risk" mammographic patterns to histological risk factors for development of cancer in the human breast. Br J Radiol 1990, 63:845-849.

32. Boyd NF, Jensen HM, Cooke G, Han HL: Relationship between mammographic and histological risk factors for breast cancer. J Natl Cancer Inst 1992, 84:1170-1179

33. Lin SJ, Cawson J, Hill P, Haviv I, Jenkins M, Hopper JL, Southey MC, Campbell IG: Image-guided sampling reveals increased stroma and lower glandular complexity in mammographically dense breast tissue. Breast Cancer Res Treat 2011, 128:505-516.

34. Vachon CM, Sasano H, Ghosh K, Brandt KR, Watson DA, Reynolds C, Lingle WL, Goss PE, Li R, Aiyar SE, Scott CG, Pankratz VS, Santen RJ: Aromatase immunoreactivity is increased in mammographically dense regions of the breast. Breast Cancer Res Treat 2011, 125:243-252.

35. Anderson E, Clarke RB, Howell A: Estrogen responsiveness and control of normal human breast proliferation. J Mammary Gland Biol Neoplasia 1998, 3:23-35.

36. Russo $I H$, Russo J: Primary prevention of breast cancer by hormoneinduced differentiation. Recent Results Cancer Res 2007, 174:111-130.

37. Li T, Sun L, Miller N, Nicklee T, Woo J, Hulse-Smith L, Tsao MS, Khokha R, Martin L, Boyd N: The association of measured breast tissue characteristics with mammographic density and other risk factors for breast cancer. Cancer Epidemiol Biomarkers Prev 2005, 14:343-349.

38. Wang X, Goode EL, Fredericksen ZS, Vierkant RA, Pankratz VS, Liu-Mares W, Rider DN, Vachon CM, Cerhan JR, Olson JE, Couch FJ: Association of genetic variation in genes implicated in the beta-catenin destruction complex with risk of breast cancer. Cancer Epidemiol Biomarkers Prev 2008, 17:2101-2108.

39. Byng JW, Boyd NF, Fishell E, Jong RA, Yaffe MJ: The quantitative analysis of mammographic densities. Phys Med Biol 1994, 39:1629-1638.

40. Vachon CM, Sellers TA, Janney CA, Brandt KR, Carlson EE, Pankratz VS, Wu FF, Therneau TM: Alcohol intake in adolescence and mammographic density. Int J Cancer 2005, 117:837-841.

41. Cerhan JR, Sellers TA, Janney CA, Pankratz VS, Brandt KR, Vachon CM: Prenatal and perinatal correlates of adult mammographic breast density. Cancer Epidemiol Biomarkers Prev 2005, 14:1502-1508.

42. Kelemen LE, Pankratz VS, Sellers TA, Brandt KR, Wang A, Janney C, Fredericksen ZS, Cerhan JR, Vachon CM: Age-specific trends in mammographic density: the Minnesota Breast Cancer Family Study. Am J Epidemiol 2008, 167:1027-1036.

43. Vachon CM, Brandt KR, Ghosh K, Scott CG, Maloney SD, Carston MJ, Pankratz VS, Sellers TA: Mammographic breast density as a general marker of breast cancer risk. Cancer Epidemiol Biomarkers Prev 2007, 16:43-49.

44. Kittler R, Putz G, Pelletier L, Poser I, Heninger AK, Drechsel D, Fischer S, Konstantinova I, Habermann B, Grabner H, Yaspo ML, Himmelbauer H, Korn B, Neugebauer K, Pisabarro MT, Buchholz F: An endoribonucleaseprepared siRNA screen in human cells identifies genes essential for cell division. Nature 2004, 432:1036-1040.

45. Bettencourt-Dias M, Giet R, Sinka R, Mazumdar A, Lock WG, Balloux F, Zafiropoulos PJ, Yamaguchi S, Winter S, Carthew RW, Cooper M, Jones D, Frenz L, Glover DM: Genome-wide survey of protein kinases required for cell cycle progression. Nature 2004, 432:980-987.

46. Olson JE, Wang X, Pankratz VS, Fredericksen ZS, Vachon CM, Vierkant RA, Cerhan JR, Couch FJ: Centrosome-related genes, genetic variation, and risk of breast cancer. Breast Cancer Res Treat 2010, 125:221-228.

47. Carlson CS, Eberle MA, Rieder MJ, Yi Q, Kruglyak L: Selecting a maximally informative set of single-nucleotide polymorphisms for association analyses using linkage disequilibrium. Am J Hum Genet 2004, 74:106-120

48. Steemers FJ, Gunderson KL: Illumina, Inc. Pharmacogenomics 2005, 6:777-782

49. Oliphant A, Barker DL, Stuelpnagel JR, Chee MS: BeadArray technology: enabling an accurate, cost-effective approach to high-throughput genotyping. Biotechniques 2002, Suppl: 56-58, 60, 51 .

50. Fan JB, Hu SX, Craumer WC: BeadArray-based solutions for enabling the promise of pharmacogenomics. Biotechniques 2005, 39:583-588.

51. Li J, Eriksson L, Humphreys K, Czene K, Liu J, Tamimi RM, Lindström S, Hunter DJ, Vachon CM, Couch FJ, Scott CG, Lagiou P, Hall P: Genetic variation in the estrogen metabolic pathway and mammographic density as an intermediate phenotype of breast cancer. Breast Cancer Res 2010, 12:R19.

52. Li J, Humphreys K, Heikkinen T, Aittomäki K, Blomqvist C, Pharoah PD, Dunning AM, Ahmed S, Hooning MJ, Martens JW, van den Ouweland AM, Alfredsson L, Palotie A, Peltonen-Palotie L, Irwanto A, Low HQ, Teoh GH, Thalamuthu A, Easton DF, Nevanlinna H, Liu J, Czene K, Hall P: A combined analysis of genome-wide association studies in breast cancer. Breast Cancer Res Treat 2011, 126:717-727. 
53. Byng JW, Boyd NF, Little L, Lockwood G, Fishell E, Jong RA, Yaffe MJ: Symmetry of projection in the quantitative analysis of mammographic images. Eur I Cancer Prev 1996, 5:319-327.

54. Chai HS, Sicotte H, Bailey KR, Turner ST, Asmann YW, Kocher JP: GLOSSI: a method to assess the association of genetic loci-sets with complex diseases. BMC Bioinformatics 2009, 10:102

55. Cochran WG: The combination of estimates from different experiments. Biometrics 1954, 10:101-129.

56. Galwey NW: A new measure of the effective number of tests, a practical tool for comparing families of non-independent significance tests. Genet Epidemiol 2009, 33:559-568.

57. Ganem NJ, Godinho SA, Pellman D: A mechanism linking extra centrosomes to chromosomal instability. Nature 2009, 460:278-282.

58. Montoya-Durango DE, Velu CS, Kazanjian A, Rojas ME, Jay CM, Longmore GD, Grimes HL: Ajuba functions as a histone deacetylasedependent co-repressor for autoregulation of the growth factorindependent-1 transcription factor. J Biol Chem 2008, 283:32056-32065.

59. Hawes D, Downey S, Pearce CL, Bartow S, Wan P, Pike MC, Wu AH: Dense breast stromal tissue shows greatly increased concentration of breast epithelium but no increase in its proliferative activity. Breast Cancer Res 2006, 8:R24.

doi: $10.1186 / \mathrm{bcr} 3088$

Cite this article as: Vachon et al: No evidence for association of

inherited variation in genes involved in mitosis and percent

mammographic density. Breast Cancer Research 2012 14:R7.

\section{Submit your next manuscript to BioMed Central} and take full advantage of:

- Convenient online submission

- Thorough peer review

- No space constraints or color figure charges

- Immediate publication on acceptance

- Inclusion in PubMed, CAS, Scopus and Google Scholar

- Research which is freely available for redistribution

Submit your manuscript at www.biomedcentral.com/submit 